\title{
The effect of cation source and dietary cation-anion difference on rumen ion concentrations in lactating dairy cows
}

\author{
T. L. Catterton and R. A. Erdman ${ }^{1}$ \\ Animal and Avian Sciences Department, University of Maryland, College Park 20742
}

\begin{abstract}
Many studies have focused on the influence of dietary cation-anion difference (DCAD) on animal performance but few have examined the effect of DCAD on the rumen ionic environment. The objective of this study was to examine the effects of DCAD, cation source ( $\mathrm{Na}$ vs. $\mathrm{K}$ ), and anion source ( $\mathrm{Cl}$ vs. bicarbonate or carbonate) on rumen environment and fermentation. The study used 5 rumen-fistulated dairy cows and 5 dietary treatments that were applied using a $5 \times 5$ Latin square design with 2 -wk experimental periods. Treatments consisted of (1) the basal total mixed ration (TMR); (2) the basal TMR plus $340 \mathrm{mEq} / \mathrm{kg}$ of $\mathrm{Na}$ (dry matter basis) using $\mathrm{NaCl}$; (3) the basal TMR plus $340 \mathrm{mEq} /$ $\mathrm{kg}$ of $\mathrm{K}$ using $\mathrm{KCl}$; (4) the basal TMR plus $340 \mathrm{mEq} /$ $\mathrm{kg}$ of $\mathrm{Na}$ using $\mathrm{NaHCO}_{3}$; and (5) the basal TMR plus $340 \mathrm{mEq} / \mathrm{kg}$ of $\mathrm{K}$ using $\mathrm{K}_{2} \mathrm{CO}_{3}$. On the last day of each experimental period, rumen samples were collected and pooled from 5 different locations at $0,1.5,3,4.5,6,9$, and $12 \mathrm{~h}$ postfeeding for measurement of rumen $\mathrm{pH}$ and concentrations of strong ions and volatile fatty acids (VFA). Dietary supplementation of individual strong ions increased the corresponding rumen ion concentration. Rumen $\mathrm{Na}$ was decreased by $24 \mathrm{mEq} / \mathrm{L}$ when $\mathrm{K}$ was substituted for $\mathrm{Na}$ in the diet, but added dietary $\mathrm{Na}$ had no effect on rumen K. Rumen $\mathrm{Cl}$ was increased by $10 \mathrm{mEq} / \mathrm{L}$ in diets supplemented with $\mathrm{Cl}$. Cation source had no effect on rumen $\mathrm{pH}$ or total VFA concentration. Increased DCAD increased rumen $\mathrm{pH}$ by 0.10 $\mathrm{pH}$ units and increased rumen acetate by $4 \mathrm{mEq} / \mathrm{L}$ but did not increase total VFA. This study demonstrated that rumen ion concentrations can be manipulated by dietary ion concentrations. If production and feed efficiency responses to DCAD and ionophores in the diet are affected by rumen $\mathrm{Na}$ and $\mathrm{K}$ concentrations, then manipulating dietary $\mathrm{Na}$ and $\mathrm{K}$ could be used either to enhance or diminish those responses.
\end{abstract}

Key words: dietary cation-anion difference, rumen ions, dairy cattle

Received January 4, 2016

Accepted April 21, 2016.

${ }^{1}$ Corresponding author: erdman@umd.edu

\section{INTRODUCTION}

Dietary cation-anion difference is used as a tool to evaluate the strong ion $(\mathrm{Na}, \mathrm{K}$, and $\mathrm{Cl})$ balance in formulation of dairy cattle diets; DCAD $(\mathrm{mEq} / \mathrm{kg}$ of DM) can be calculated as $\mathrm{Na}+\mathrm{K}-\mathrm{Cl}$ (Mongin, 1981; Tucker et al., 1988) or as $\mathrm{Na}+\mathrm{K}-\mathrm{Cl}-\mathrm{S}$ (Ender et al., 1962). Although extensive research has shown that manipulating DCAD can increase performance by improving feed intake, milk production, and acid-base status of the animal (Mongin, 1981; Tucker et al., 1988; $\mathrm{Hu}$ and Murphy, 2004), little research has been done to examine the effects of the individual ions that contribute to DCAD or the effect of DCAD on the rumen environment. Although the effect of diet on the rumen ion environment has been studied previously (Bailey, 1961; Bennink et al., 1978), to our knowledge, only one study has investigated the effect of DCAD on rumen ion concentrations (Tucker et al., 1988).

Increasing DCAD enhances animal performance by increasing DMI, milk yield, and feed efficiency (Tucker et al., 1988; Sanchez et al., 1994; Hu and Murphy, 2004). In addition to total DCAD, there is some evidence that cation source may affect animal performance. Iwaniuk et al. (2015) found that substitution of $\mathrm{Na}$ for $\mathrm{K}$ as the supplemental cation source in DCAD constant diets increased milk fat percentage and fat yield. In contrast, Wildman et al. (2007) and Hu and Kung (2009) found no effect of cation source on these parameters when DCAD remained constant. Unfortunately, none of these studies measured rumen ion concentrations or considered the rumen cation-anion difference (RCAD). Tucker et al. (1988) did measure rumen parameters when using different combinations of ions to achieve specific DCAD values but only reported the results by DCAD concentration and not by the different ion concentrations used to achieve each DCAD.

Although $\mathrm{Na}$ is the predominant cation in rumen fluid, Bennink et al. (1978) demonstrated that dietary $\mathrm{Na}$ and $\mathrm{K}$ could influence the respective rumen concentrations of $\mathrm{Na}$ and $\mathrm{K}$. Shifts in rumen $\mathrm{Na}$ and $\mathrm{K}$ concentrations could potentially mediate rumen fermentation responses to ionophores. Ionophores form complexes with specific cations, and these complexes 
bind to cell walls of bacteria, resulting in extracellular $\mathrm{Na}$ replacing intracellular K, limiting the bacteria's ability to function and divide (McGuffey et al., 2001; Ipharraguerre and Clark, 2003). Monensin binds Na ions with 10 times the affinity that it binds $\mathrm{K}$ ions, whereas lasalocid binds $\mathrm{K}$ ions with 3 to 10 times the affinity that it binds $\mathrm{Na}$ ions (McGuffey et al., 2001). Newbold et al. (2013) recently demonstrated increased monensin sensitivity in rumen bacteria by increasing media $\mathrm{Na}$, but reduced monensin sensitivity in media with increased $\mathrm{K}$. These results support previous in vivo evidence (Rumpler et al., 1986) that showed a much greater reduction in methane production in steers fed monensin or lasalocid when supplemented with added dietary $\mathrm{Na}$ but not with added dietary K. Further, rumen propionate responses to lasalocid were attenuated in lambs supplemented with K (Funk et al., 1986).

The previous in vivo (Funk et al., 1986; Rumpler et al., 1986; Iwaniuk et al., 2015) and in vitro studies (Newbold et al., 2013) suggested that, in addition to DCAD concentration, cation source and changes in rumen ion concentrations might also influence rumen fermentation and production responses. Our hypothesis was that dietary strong ion concentrations and DCAD affect rumen ion concentrations. The objective of this study was to examine the effects of DCAD, cation source, and anion source on the rumen ionic environment and further examine their effects on rumen fermentation.

\section{MATERIALS AND METHODS}

\section{Research Facilities and Animals}

All procedures involving animals were carried out as approved by the Institutional Animal Care and Use Committee at the University of Maryland. Animals were housed at the Central Maryland Research and Education Center in Ellicott City, Maryland. Five rumen-fistulated, multiparous Holstein cows in late lactation $(245 \pm 4.5 \mathrm{DIM}$ at the start of the experiment) were used in a 10-wk study that was conducted between June and August 2014. Three cows were in early pregnancy and 2 cows were not pregnant at the start of the experiment. The cows were housed in tie stalls that were fitted with water mattresses and bedded with sawdust. Water was available ad libitum through automatic waterers located in between each stall. The cows were taken out of the barn for milking twice daily, at approximately 0615 and $1530 \mathrm{~h}$. Stalls were cleaned and bedded while the cows were out of the barn for milking. Fans were used to help increase air circulation and reduce temperatures in the barn. The barn photoperiod during the study was $16 \mathrm{~h}$ of light and $8 \mathrm{~h}$ of dark. Cows were individually fed a TMR once daily, at $0700 \mathrm{~h}$, and had continuous access to feed except when they were turned out for milking.

\section{Experimental Diets}

Cows were fed a TMR formulated to meet or exceed the NRC (2001) requirements for cows producing $40 \mathrm{~kg}$ of milk per day. The TMR basal diet consisted of $57.4 \%$ corn silage and $8.4 \%$ alfalfa hay as the forages (DM basis), with the remainder of the diet consisting of ground corn, soybean meal ( $48 \% \mathrm{CP})$, and a vitamin-mineral premix using corn gluten meal as the carrier. Ingredient composition of the basal and treatment diets is shown in Table 1. The basal TMR was prepared in a Calan Data Ranger feed mixer (American Calan, Northwood, $\mathrm{NH}$ ). Feed was dispensed into individual feed bins, with each cow receiving enough feed to generate an as-fed feed refusal rate of 2 to $4 \mathrm{~kg} / \mathrm{d}$.

Experimental treatments consisted of (1) the basal TMR (Basal); (2) the basal TMR plus $340 \mathrm{mEq} /$ $\mathrm{kg}$ added $\mathrm{Na}$ (DM basis) using supplemental sodium chloride $(\mathrm{NaCl})$; (3) the basal TMR plus $340 \mathrm{mEq} / \mathrm{kg}$ added $\mathrm{K}$ using supplemental potassium chloride $(\mathrm{KCl})$; (4) the basal TMR plus $340 \mathrm{mEq} / \mathrm{kg}$ added Na using supplemental sodium bicarbonate $\left(\mathrm{NaHCO}_{3}\right)$; and (5) the basal TMR plus $340 \mathrm{mEq} / \mathrm{kg}$ added $\mathrm{K}$ using supplemental potassium carbonate $\left(\mathrm{K}_{2} \mathrm{CO}_{3}\right)$. The level of supplementation, $340 \mathrm{mEq}$ per $\mathrm{kg}$ of diet DM equivalent to $0.78 \%$ and $1.33 \%$ added $\mathrm{Na}$ and $\mathrm{K}$, respectively, was selected to ensure a treatment response while keeping within the expected potential range of DCAD and $\mathrm{K}$ concentrations observed when feeding ingredients with high $\mathrm{K}$ and $\mathrm{Cl}$ concentrations such as in diets containing small grain silages and alfalfa. Treatments were applied in a $5 \times 5$ Latin square design with 2 -wk experimental periods.

During each experimental period, there was only one cow per dietary treatment. Thus, to prevent the loss of mineral supplements during the feed mixing process, treatment mineral supplements were added to the basal TMR for each cow in their individual feeding tubs and then mixed with a pitchfork. The mineral treatments supplied an additional $342 \pm 0.4$ (average \pm SEM) $\mathrm{mEq} / \mathrm{kg}$ of diet DM of either $\mathrm{Na}$ or K. Diets that were supplemented with chloride received an additional 347 \pm 4.1 (average $\pm \mathrm{SEM}$ ) $\mathrm{mEq} / \mathrm{kg}$ of diet $\mathrm{DM}$ of $\mathrm{Cl}$. Table 2 shows the chemical composition of the experimental diets.

\section{Measurements}

Cows were weighed after the morning milking before feeding on the last day of wk 1 and 2 of each 
Table 1. The ingredient composition of the experimental diets on a DM basis

\begin{tabular}{|c|c|c|c|c|c|}
\hline \multirow[b]{2}{*}{ Item } & \multicolumn{5}{|c|}{ Treatment $^{1}$} \\
\hline & Basal & $\mathrm{NaCl}$ & $\mathrm{KCl}$ & $\mathrm{NaHCO}_{3}$ & $\mathrm{~K}_{2} \mathrm{CO}_{3}$ \\
\hline Corn silage & 57.41 & 56.26 & 55.87 & 55.76 & 56.03 \\
\hline Alfalfa hay & 8.37 & 8.20 & 8.14 & 8.13 & 8.16 \\
\hline Ground corn & 10.87 & 10.66 & 10.58 & 10.56 & 10.61 \\
\hline Soybean meal & 15.30 & 15.00 & 14.89 & 14.87 & 14.94 \\
\hline Soyplus $^{2}$ & 3.41 & 3.35 & 3.33 & 3.32 & 3.34 \\
\hline Corn gluten meal & 0.60 & 0.59 & 0.59 & 0.59 & 0.59 \\
\hline Dynamate $^{3}$ & 0.13 & 0.13 & 0.13 & 0.13 & 0.13 \\
\hline Biophos $^{4}$ & 0.43 & 0.42 & 0.42 & 0.42 & 0.42 \\
\hline Limestone $^{5}$ & 0.61 & 0.59 & 0.59 & 0.59 & 0.59 \\
\hline Magnesium oxide & 0.34 & 0.33 & 0.33 & 0.33 & 0.33 \\
\hline ADE $\operatorname{mix}^{6}$ & 0.03 & 0.03 & 0.03 & 0.03 & 0.03 \\
\hline Vitamin $\mathrm{E}^{7}$ & 0.01 & 0.01 & 0.01 & 0.01 & 0.01 \\
\hline Megalac $^{8}$ & 1.46 & 1.43 & 1.42 & 1.42 & 1.43 \\
\hline Selenium ${ }^{9}$ & 0.06 & 0.06 & 0.06 & 0.06 & 0.06 \\
\hline Omigen-AF $\mathrm{AF}^{10}$ & 0.20 & 0.19 & 0.19 & 0.19 & 0.19 \\
\hline TM- $433^{11}$ & 0.03 & 0.03 & 0.03 & 0.03 & 0.03 \\
\hline 4 -Plex $\mathrm{C}^{12}$ & 0.01 & 0.01 & 0.01 & 0.01 & 0.01 \\
\hline Diamond $\mathrm{V} \mathrm{XP}^{13}$ & 0.24 & 0.23 & 0.23 & 0.23 & 0.23 \\
\hline $\mathrm{NaCl}^{14}$ & 0.49 & 2.48 & 0.47 & 0.47 & 0.48 \\
\hline $\mathrm{KCl}$ & 0.00 & 0.00 & 2.68 & 0.00 & 0.00 \\
\hline $\mathrm{NaHCO}_{3}$ & 0.00 & 0.00 & 0.00 & 2.87 & 0.00 \\
\hline $\mathrm{K}_{2} \mathrm{CO}_{3}$ & 0.00 & 0.00 & 0.00 & 0.00 & 2.39 \\
\hline
\end{tabular}

${ }^{1}$ The basal diet was supplemented with the indicated salt for the treatment diets. The $\mathrm{NaCl}$ diet contained (DM basis) an additional $343 \mathrm{mEq} / \mathrm{kg}$ of $\mathrm{Na}$ and $\mathrm{Cl}$. The $\mathrm{KCl}$ diet contained an additional $343 \mathrm{mEq} / \mathrm{kg}$ of $\mathrm{K}$ and $351 \mathrm{mEq} / \mathrm{kg}$ of $\mathrm{Cl}$. The $\mathrm{NaHCO}_{3}$ diet contained an additional $341 \mathrm{mEq} / \mathrm{kg}$ of $\mathrm{Na}$. The $\mathrm{K}_{2} \mathrm{CO}_{3}$ diet contained an additional $343 \mathrm{mEq} / \mathrm{kg}$ of $\mathrm{K}$.

${ }^{2}$ West Central Cooperative (Ralston, IA).

${ }^{3}$ Contained $11.5 \% \mathrm{Mg}, 18 \% \mathrm{~K}$, and $22.5 \% \mathrm{~S}$ (Mosaic Co., Plymouth, MN).

${ }^{4}$ Contained $17 \% \mathrm{Ca}$ and $21 \% \mathrm{P}$.

${ }^{5}$ Contained $36 \% \mathrm{Ca}$ and $0.02 \% \mathrm{P}$.

${ }^{6}$ Contained 5,454,545 IU/ $\mathrm{kg}$ of vitamin A, 1,818,182 IU/kg of vitamin D, 9,091 IU/kg of vitamin E.

${ }^{7}$ Contained $56,818 \mathrm{IU} / \mathrm{kg}$ of vitamin E.

${ }^{8}$ Contained $9 \%$ Ca; $84.5 \%$ fat (Church \& Dwight Co. Inc., Piscataway, NJ).

${ }^{9}$ Contained $600 \mathrm{mg} \mathrm{Se} / \mathrm{kg}, 28 \% \mathrm{Ca}$.

${ }^{10}$ Contained $0.41 \mathrm{mg} / \mathrm{kg}$ of biotin, $15 \mathrm{mg} / \mathrm{kg}$ of choline, $31 \mathrm{mg} / \mathrm{kg}$ of D-pantothenic acid, $1.4 \mathrm{mg} / \mathrm{kg}$ of folic acid, $3.2 \mathrm{mg} / \mathrm{kg}$ of menadione, $102 \mathrm{mg} / \mathrm{kg}$ of niacin, $30 \mathrm{mg} / \mathrm{kg}$ of riboflavin, $4.5 \times 10^{10} \mathrm{cfu} / \mathrm{kg}$ Saccharomyces cerevisiae, $15 \mathrm{mg} / \mathrm{kg}$ of thiamine, $8.2 \mathrm{mg} / \mathrm{kg}$ of vitamin $\mathrm{B}_{6}$, and $41 \mu \mathrm{g} / \mathrm{kg}$ of vitamin $\mathrm{B}_{12}$ (Prince Agri Products, Inc., Quincy, IL).

${ }^{11}$ Contained $0.16 \%$ Co, $4.0 \%$ Cu, 3.0\% Fe, 0.35\% I, 15\% Mn, and 16\% Zn (Southern States Cooperative Inc., Richmond, VA).

${ }^{12}$ Contained $0.36 \%$ Co, $1.80 \%$ Cu, 2.86\% Mn, and 5.15\% Zn (Zinpro Corporation, Eden Prairie, MN).

${ }^{13}$ Contained Saccharomyces cerevisiae yeast (Diamond V, Cedar Rapids, IA).

${ }^{14}$ Additional salt was given to cows when receiving the $\mathrm{NaCl}$ treatment.

experimental period. Individual milk production was recorded electronically at each milking. Milk samples were collected during the last 6 milkings of each experimental period and were analyzed for milk fat, protein, SCC, other solids (lactose and minerals), and MUN at the Lancaster DHIA (Lancaster, PA). The amounts of feed offered and refused (weighed just before the next feeding) was measured once daily for each cow.

Samples of individual feed ingredients including corn silage, alfalfa hay, ground corn, soybean meal, and the vitamin mineral premix were collected weekly, pooled together by ingredient for the entire study, and sent to Cumberland Valley Analytical Service (Hagerstown,
$\mathrm{MD}$ ) for analysis of $\mathrm{DM}, \mathrm{CP}, \mathrm{ADF}, \mathrm{NDF}$, lignin and ether extract. Feed $\mathrm{Ca}, \mathrm{P}, \mathrm{Mg}, \mathrm{Na}$, and $\mathrm{K}$ were determined by inductively coupled plasma emission spectroscopy, $\mathrm{Cl}$ by potentiometric titration with silver nitrate, and S using a Leco S632 Sulfur Combustion Analyzer as reported in the feed laboratory procedures (Cumberland Valley Analytical Services, 2016). Corn silage DM was measured weekly using a Koster Tester (Koster Moisture Tester Inc., Brunswick, $\mathrm{OH}$ ) to adjust the as-fed composition of the TMR to maintain a constant ingredient composition on a DM basis.

Rumen samples were collected on the last day of each period. Samples were collected at 0, 1.5, 3, 4.5, 6, 9, and 
Table 2. The chemical composition of the experimental diets on a DM basis

\begin{tabular}{|c|c|c|c|c|c|c|}
\hline \multirow[b]{2}{*}{ Item } & \multicolumn{5}{|c|}{ Treatment $^{1}$} & \multirow[b]{2}{*}{ SEM } \\
\hline & Basal & $\mathrm{NaCl}$ & $\mathrm{KCl}$ & $\mathrm{NaHCO}_{3}$ & $\mathrm{~K}_{2} \mathrm{CO}_{3}$ & \\
\hline DM, \% & 42.8 & 43.3 & 43.5 & 43.5 & 43.3 & 0.13 \\
\hline $\mathrm{NE}_{\mathrm{L}}, \mathrm{Mcal} / \mathrm{kg}$ & 1.63 & 1.59 & 1.58 & 1.58 & 1.59 & 0.01 \\
\hline $\mathrm{CP}, \%$ & 16.3 & 16.0 & 15.9 & 15.8 & 15.9 & 0.08 \\
\hline NDF, $\%$ & 28.1 & 27.5 & 27.3 & 27.3 & 27.4 & 0.15 \\
\hline $\mathrm{ADF}, \%$ & 20.5 & 20.0 & 19.9 & 19.9 & 20.0 & 0.11 \\
\hline Lignin, \% & 3.51 & 3.44 & 3.42 & 3.41 & 3.43 & 0.02 \\
\hline Ash, \% & 7.53 & 9.38 & 10.01 & 10.2 & 9.74 & 0.479 \\
\hline Fat, $^{2} \%$ & 2.62 & 2.56 & 2.55 & 2.54 & 2.55 & 0.014 \\
\hline $\mathrm{Na}, \%$ & 0.25 & 1.03 & 0.24 & 1.03 & 0.24 & 0.192 \\
\hline $\mathrm{K}, \%$ & 1.56 & 1.53 & 2.85 & 1.51 & 2.86 & 0.325 \\
\hline $\mathrm{Cl}, \%$ & 0.57 & 1.77 & 1.80 & 0.55 & 0.56 & 0.300 \\
\hline S, $\%$ & 0.23 & 0.22 & 0.22 & 0.22 & 0.22 & 0.001 \\
\hline $\mathrm{Ca}, \%$ & 0.91 & 0.89 & 0.89 & 0.88 & 0.89 & 0.005 \\
\hline $\mathrm{P}, \%$ & 0.53 & 0.52 & 0.51 & 0.51 & 0.51 & 0.003 \\
\hline $\mathrm{Mg}, \%$ & 0.39 & 0.38 & 0.38 & 0.38 & 0.38 & 0.002 \\
\hline $\mathrm{DCAD},{ }^{3} \mathrm{mEq} / \mathrm{kg}$ & 346 & 339 & 329 & 677 & 681 & 83.6 \\
\hline DCAD-S, ${ }^{4} \mathrm{mEq} / \mathrm{kg}$ & 204 & 199 & 190 & 538 & 541 & 83.7 \\
\hline
\end{tabular}

${ }^{1}$ The basal diet was supplemented with the indicated salt for the treatment diets. The $\mathrm{NaCl}$ diet contained (DM basis) an additional $343 \mathrm{mEq} / \mathrm{kg}$ of $\mathrm{Na}$ and $\mathrm{Cl}$. The $\mathrm{KCl}$ diet contained an additional $343 \mathrm{mEq} / \mathrm{kg}$ of $\mathrm{K}$ and $351 \mathrm{mEq} / \mathrm{kg}$ of $\mathrm{Cl}$. The $\mathrm{NaHCO}_{3}$ diet contained an additional $341 \mathrm{mEq} / \mathrm{kg}$ of Na. The $\mathrm{K}_{2} \mathrm{CO}_{3}$ diet contained an additional $343 \mathrm{mEq} / \mathrm{kg}$ of $\mathrm{K}$.

${ }^{2}$ Crude fat, which does not account for the $1.23 \%$ fatty acids provided by Megalac (Arm and Hammer Animal Nutrition, Piscataway, NJ) in the basal diet ( $84.5 \%$ of $1.46 \%$ diet DM) and the $1.20 \%$ and $1.21 \%$ fatty acids provided in the treatment diets $(84.5 \%$ of $1.42 \%$ and $1.43 \%$ diet DM).

${ }^{3} \mathrm{DCAD}=\mathrm{Na}+\mathrm{K}-\mathrm{Cl}$.

${ }^{4} \mathrm{DCAD}-\mathrm{S}=\mathrm{Na}+\mathrm{K}-\mathrm{Cl}-\mathrm{S}$.

$12 \mathrm{~h}$ postfeeding, with time 0 being just before feeding. Rumen fluid was collected in a $60-\mathrm{mL}$ syringe using a $50-\mathrm{cm}$ stainless steel tube with a mesh strainer at the end (RT Rumen Fluid Sampler Tube, Bar Diamond Inc., Parma, ID). Ten milliliters of fluid was collected and pooled from 5 different locations: the atrial, dorsal, ventral, caudodorsal, and caudoventral areas of the rumen, which gave a total of $50 \mathrm{~mL}$ of fluid collected at each sampling time.

The rumen fluid $\mathrm{pH}$ was measured immediately after sampling with a $\mathrm{pH}$ probe. A $10-\mathrm{mL}$ aliquot was added to a $15-\mathrm{mL}$ polypropylene Falcon tube containing 0.2 $\mathrm{mL}$ of $50 \%$ sulfuric acid and frozen at $-20^{\circ} \mathrm{C}$ for later analysis of VFA. The remaining $40 \mathrm{~mL}$ of rumen fluid was frozen for later analysis of ion concentrations. $\mathrm{Ru}-$ men fluid VFA concentrations were determined using gas-liquid chromatography. The frozen samples were thawed in a water bath at $34^{\circ} \mathrm{C}$ and then centrifuged at $2,100 \times g$ for 30 min to clarify the rumen fluid. Samples were prepared by adding $0.7 \mathrm{~mL}$ of the supernatant to $0.3 \mathrm{~mL}$ of a phosphate buffer that contained $20 \mathrm{mEq} / \mathrm{L}$ 2-ethylbutyrate as an internal standard. A standard solution containing $80 \mathrm{mEq} / \mathrm{L}$ acetate, $35 \mathrm{mEq} / \mathrm{L}$ propionate, $5 \mathrm{mEq} / \mathrm{L}$ isobutyrate, $10 \mathrm{mEq} / \mathrm{L}$ butyrate, 5 $\mathrm{mEq} / \mathrm{L}$ isovalerate, and $5 \mathrm{mEq} / \mathrm{L}$ valerate was used to determine the response factors of the various VFA. The standard was prepared for analysis by adding $0.7 \mathrm{~mL}$ to $0.3 \mathrm{~mL}$ of the phosphate buffer with 2-ethylbutryate. Prepared samples were analyzed by a gas chromatograph (Agilent 6890, Agilent Technologies, Santa Clara, CA) with helium as the carrier gas, a flow rate of $49.1 \mathrm{~mL} / \mathrm{min}$, and a column temperature of $130^{\circ} \mathrm{C}$. The ratio of the 2-ethylbutyrate concentration within each sample was compared with an internal standard to correct for variation in injection volume.

Rumen ion concentrations were determined using flame atomic absorption spectrometry (5100 PC, PerkinElmer, Norwalk, CT). Frozen rumen fluid samples were thawed in a water bath at $34^{\circ} \mathrm{C}$ and then centrifuged at $2,100 \times g$ for 30 min with the supernatant used for mineral analyses. The protocols for measuring ion concentrations were adapted from procedures described by PerkinElmer (1996) and Agilent Technologies (2015). Sodium and potassium were directly measured from rumen fluid that had been diluted with deionized water 3,333 times to be within the linear range of absorption for the ion lamp used. Sodium concentrations were measured using a wavelength of $589.0 \mathrm{~nm}$ and a slit width of $0.4 \mathrm{~nm}$. Potassium concentrations were measured using a wavelength of $766.5 \mathrm{~nm}$ and a slit width of $0.4 \mathrm{~nm}$. Rumen chloride concentrations were measured indirectly using silver chloride precipitation. In this procedure, $2.5 \mathrm{~mL}$ of rumen fluid, $1 \mathrm{~mL}$ of $\mathrm{HNO}_{3}, 5$ $\mathrm{mL}$ of $0.046 \mathrm{M} \mathrm{AgNO}_{3}$, and $41.5 \mathrm{~mL}$ of deionized water 
were combined, mixed, and then centrifuged at 1,303 $\times g$ for $10 \mathrm{~min}$. The supernatant containing unprecipitated $\mathrm{Ag}$ was analyzed for $\mathrm{Ag}$ by atomic absorption using a wavelength of $338.3 \mathrm{~nm}$ and a slit width of 0.7 $\mathrm{nm}$. The chloride concentration was then calculated by the following equation (PerkinElmer, 1996):

$$
\begin{gathered}
\mathrm{Cl}, \mathrm{mg} / \mathrm{L}=[500-(100 \times \mathrm{Ag}, \mathrm{mg} / \mathrm{L})] \\
\times 6.58 \times \text { dilution factor } .
\end{gathered}
$$

All mineral concentrations in rumen fluid were converted to milliequivalents per liter by dividing by their respective atomic mass. Finally, the RCAD in rumen fluid was calculated using the following equation:

$$
\operatorname{RCAD}(\mathrm{mEq} / \mathrm{L})=\mathrm{Na}+\mathrm{K}-\mathrm{Cl} .
$$

\section{Data Summarization and Statistical Analysis}

Measurements collected during the last $3 \mathrm{~d}$ of each experimental period were used to calculate DMI, milk production, milk composition and component yields, and feed efficiency for each cow. Milk fat, protein, and other solids yields were calculated as the individual component concentration multiplied by its respective milk yield at each milking to calculate a mean daily yield for each cow. The 3.5\% FCM was determined as described by Erdman (2011) using the following equation:

$$
\begin{gathered}
3.5 \% \text { FCM }, \mathrm{kg} / \mathrm{d}=[0.4318 \times \text { milk }(\mathrm{kg} / \mathrm{d})] \\
+[16.23 \times \text { milk fat }(\mathrm{kg} / \mathrm{d})] .
\end{gathered}
$$

Feed efficiency was calculated as 3.5\% FCM divided by DMI.

Dry matter intake, milk production, milk composition, and feed efficiency data were summarized by cow within each experimental period and analyzed using the MIXED procedure in SAS (SAS Institute Inc., Cary, NC) using a statistical model that included fixed effects of cow, period, and treatment, with cow within treatment serving as the experimental unit. A repeatedmeasures design with compound symmetry structure was used for the analysis of rumen $\mathrm{pH}$, ion, and VFA concentrations with a model that included the effects of cow, treatment, period, cow within treatment, time postfeeding, and the interaction of time postfeeding and treatment. Cow within treatment and period were considered as random effects and used to test the effects of treatment, whereas time postfeeding and the time postfeeding by treatment interaction were tested using residual error. Four a priori comparisons were used to compare the effects of (1) cation source $(\mathrm{NaCl}$ and $\mathrm{NaHCO}_{3}$ vs. $\mathrm{KCl}$ and $\mathrm{K}_{2} \mathrm{CO}_{3}$ ); (2) anion source ( $\mathrm{NaCl}$ and $\mathrm{KCl}$ vs. $\mathrm{NaHCO}_{3}$ and $\mathrm{K}_{2} \mathrm{CO}_{3}$ ); (3) DCAD (Basal, $\mathrm{NaCl}$, and $\mathrm{KCl}$ vs. $\mathrm{NaHCO}_{3}$ and $\mathrm{K}_{2} \mathrm{CO}_{3}$ ); and (4) Basal vs. $\mathrm{NaCl}$ and $\mathrm{KCl}$ using the contrast statement in the MIXED procedure.

A probability of $P<0.05$ was considered statistically significant, and a probability of $0.05<P<0.10$ was considered to be a trend. Data from one cow receiving the $\mathrm{NaHCO}_{3}$ treatment during the first period was omitted for that period because she developed a severe case of mastitis. However, the cow subsequently recovered and her data were used for the remainder of the experiment. Two of the samples used for VFA analysis, one for the $\mathrm{NaCl}$ treatment and one for the $\mathrm{NaHCO}_{3}$ treatment, were excluded from the data analysis because they had outlier values for several of the VFA. To account for these missing data points, least squares means are provided, and the highest SEM is reported.

\section{RESULTS}

The chemical composition of the diets is presented in Table 2. The diets had similar nutrient composition but differed in $\mathrm{Na}, \mathrm{K}$, and $\mathrm{Cl}$, which were manipulated by treatment. The experimental diets supplied an additional $342 \pm 0.4$ (mean $\pm \mathrm{SEM}) \mathrm{mEq}$ of $\mathrm{Na}$ or $\mathrm{K} /$ $\mathrm{kg}$ of diet DM compared with the basal diet. The $\mathrm{NaCl}$ and $\mathrm{KCl}$ diets were supplied with an additional $347 \pm$ 4.1 (mean \pm SEM) $\mathrm{mEq}$ of $\mathrm{Cl} / \mathrm{kg}$ of diet $\mathrm{DM}$ compared with the other diets. The DCAD, calculated as $\mathrm{Na}+$ $\mathrm{K}-\mathrm{Cl}$, was $346,339,329,677$, and $681 \mathrm{mEq} / \mathrm{kg}$ of diet $\mathrm{DM}$ for the basal, $\mathrm{NaCl}, \mathrm{KCl}, \mathrm{NaHCO}_{3}$, and $\mathrm{K}_{2} \mathrm{CO}_{3}$ diets, respectively. The corresponding DCAD-S, calculated as $\mathrm{Na}+\mathrm{K}-\mathrm{Cl}-\mathrm{S}$, were $\sim 140 \mathrm{mEq} / \mathrm{kg}$ lower, as dietary $\mathrm{S}$ was $0.22 \%$.

Due to the small number of cows and the relatively short (2-wk) experimental periods, the study was not designed to measure production responses. Therefore, detailed information on animal performance is only available in Supplemental Table S1 (http://dx.doi. org/10.3168/jds.2016-10853). We detected no treatment effects on DMI, milk production, FCM, fat yield, protein percentage and yield, other solids (lactose and minerals) percentage and yield, SCC (linear score), MUN, and feed efficiency, which averaged $23.8 \mathrm{~kg} / \mathrm{d}$, $31.2 \mathrm{~kg} / \mathrm{d}, 31.0 \mathrm{~kg} / \mathrm{d}, 1,125 \mathrm{~g} / \mathrm{d}, 3.07 \%, 945 \mathrm{~g} / \mathrm{d}, 5.52 \%$, $1,726 \mathrm{~g} / \mathrm{d}, 3.42,14.3 \mathrm{mg} / \mathrm{dL}$, and 1.30 , respectively. Milk fat percentage was increased by 0.15 percentage units with increased DCAD $(P=0.044)$ in cows fed the $\mathrm{NaHCO}_{3}$ and $\mathrm{K}_{2} \mathrm{CO}_{3}$ treatments.

The mean BW was $695 \mathrm{~kg}(\mathrm{SEM}=4.2)$. Anion source $(P=0.001)$ and DCAD $(P=0.002)$ had significant ef- 
fects on mean BW. Cows fed the chloride diets weighed, on average, $17 \mathrm{~kg}$ more than when they were fed the carbonate diets, whereas $\mathrm{Na}$ increased $\mathrm{BW}$ by $5 \mathrm{~kg}$. Because of the short experimental periods, we interpret these changes as changes in rumen volume and perhaps overall gut fill rather than true body tissue gains and losses.

Table 3 shows the effect of treatment on rumen $\mathrm{pH}$, ion concentrations, and VFA concentrations. Rumen $\mathrm{pH}$ decreased with time postfeeding $(P=0.001$; Figure 1$)$. Mean rumen $\mathrm{pH}$ was 0.11 units higher in cows receiving the high DCAD diets $(P=0.026)$. Cation source (Na vs. K) affected rumen $\mathrm{Na}$ and $\mathrm{K}$ concentrations $(P=0.001$; Table 3$)$. Rumen Na concentrations were $11 \mathrm{mEq} / \mathrm{L}$ greater when cows were fed diets containing added $\mathrm{Na}$ compared with the basal diet $(P \leq 0.002)$ and $24 \mathrm{mEq} / \mathrm{L}$ higher than when fed diets containing added $\mathrm{K}(P=0.001)$. Rumen $\mathrm{Na}$ declined during the first $3 \mathrm{~h}$ postfeeding $(P=0.001$; Figure $2 \mathrm{~A})$, and there was a trend for a greater decline in the cows fed added $\mathrm{K}$ (treatment by time postfeeding; $P=0.091$ ).

Rumen $\mathrm{K}$ concentrations were, on average, 19.0 $\mathrm{mEq} / \mathrm{L}$ higher in cows fed added $\mathrm{K}$ (cation; $P=0.001$ ).

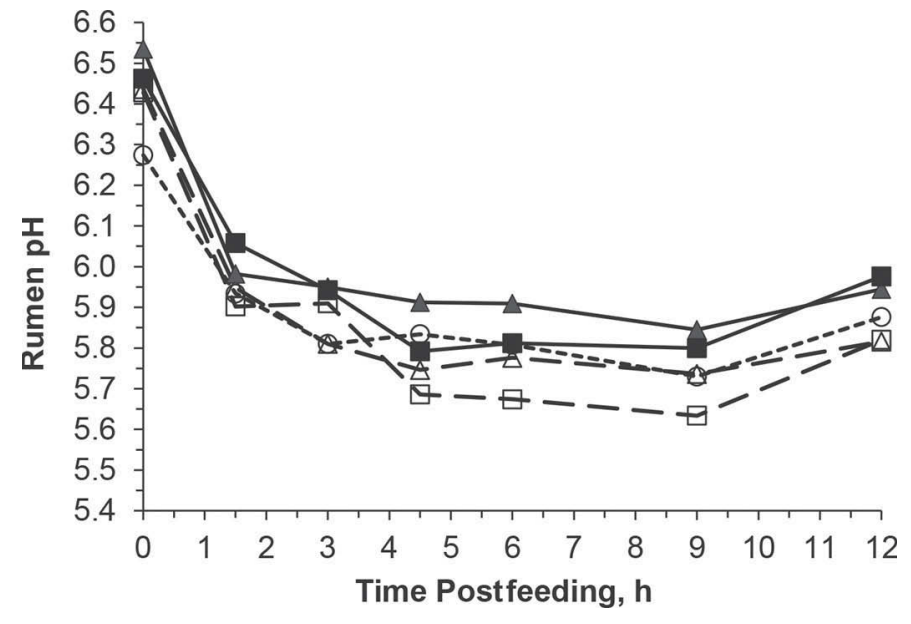

Figure 1. Time postfeeding $(P=0.001)$ and treatment by time postfeeding $(P=0.940)$ effects on rumen $\mathrm{pH}(\mathrm{SEM}=0.088)$. The basal diet (---O---) was supplemented with the indicated salt for the treatment diets. The $\mathrm{NaCl}$ diet $(--\Delta--)$ contained (DM basis) an additional $343 \mathrm{mEq} / \mathrm{kg}$ of $\mathrm{Na}$ and $\mathrm{Cl}$. The $\mathrm{KCl} \operatorname{diet}(--\square--)$ contained an additional $343 \mathrm{mEq} / \mathrm{kg}$ of $\mathrm{K}$ and $351 \mathrm{mEq} / \mathrm{kg}$ of $\mathrm{Cl}$. The $\mathrm{NaHCO}_{3} \operatorname{diet}(-\mathbf{\Lambda}-)$ contained an additional $341 \mathrm{mEq} / \mathrm{kg}$ of Na. The $\mathrm{K}_{2} \mathrm{CO}_{3}$ diet (- - ) contained an additional $343 \mathrm{mEq} / \mathrm{kg}$ of $\mathrm{K}$.

Table 3. Treatment effects on rumen $\mathrm{pH}$, strong ion, and VFA concentrations

\begin{tabular}{|c|c|c|c|c|c|c|c|c|c|c|}
\hline Item & \multicolumn{5}{|c|}{ Treatment $^{1}$} & SEM & \multicolumn{4}{|c|}{$P$-value } \\
\hline No. of cows & 5 & 5 & 5 & 4 & 5 & & & & & \\
\hline Rumen pH & 5.90 & 5.90 & 5.86 & 6.01 & 5.98 & 0.052 & 0.499 & 0.030 & 0.026 & 0.785 \\
\hline \multicolumn{11}{|c|}{ Rumen ions $(\mathrm{mEq} / \mathrm{L})$} \\
\hline $\mathrm{Na}$ & 83.8 & 93.1 & 71.8 & 96.3 & 69.5 & 1.98 & 0.001 & 0.797 & 0.999 & 0.510 \\
\hline Na:K ratio & 3.36 & 3.97 & 1.63 & 3.95 & 1.79 & 0.154 & 0.001 & 0.608 & 0.376 & 0.005 \\
\hline \multicolumn{11}{|c|}{ Rumen VFA (mEq/L) } \\
\hline Acetate $(\mathrm{A})$ & 71.5 & 70.5 & 73.3 & 75.0 & 76.9 & 1.91 & 0.187 & 0.035 & 0.020 & 0.833 \\
\hline Propionate $(\mathrm{P})$ & 24.3 & 22.4 & 23.4 & 21.7 & 23.4 & 1.12 & 0.192 & 0.731 & 0.381 & 0.234 \\
\hline Isobutyrate & 1.04 & 0.99 & 1.00 & 1.02 & 1.07 & 0.033 & 0.381 & 0.138 & 0.239 & 0.262 \\
\hline Butyrate & 10.8 & 10.5 & 10.8 & 10.8 & 11.2 & 0.42 & 0.378 & 0.358 & 0.396 & 0.712 \\
\hline
\end{tabular}

${ }^{1}$ The basal diet was supplemented with the indicated salt for the treatment diets. The $\mathrm{NaCl}$ diet contained (dry matter basis) an additional 343 $\mathrm{mEq} / \mathrm{kg}$ of $\mathrm{Na}$ and $\mathrm{Cl}$. The $\mathrm{KCl}$ diet contained an additional $343 \mathrm{mEq} / \mathrm{kg}$ of $\mathrm{K}$ and $351 \mathrm{mEq} / \mathrm{kg}$ of Cl. The $\mathrm{NaHCO}_{3}$ diet contained an additional $341 \mathrm{mEq} / \mathrm{kg}$ of Na. The $\mathrm{K}_{2} \mathrm{CO}_{3}$ diet contained an additional $343 \mathrm{mEq} / \mathrm{kg}$ of $\mathrm{K}$.

${ }^{2}$ Comparison of added dietary $\mathrm{Na}\left(\mathrm{NaCl}\right.$ and $\left.\mathrm{NaHCO}_{3}\right)$ vs. added dietary $\mathrm{K}\left(\mathrm{KCl}\right.$ and $\left.\mathrm{K}_{2} \mathrm{CO}_{3}\right)$.

${ }^{3}$ Comparison of added dietary $\mathrm{Cl}(\mathrm{NaCl}$ and $\mathrm{KCl})$ with added dietary carbonate and bicarbonate $\left(\mathrm{NaHCO}_{3}\right.$ and $\left.\mathrm{K}_{2} \mathrm{CO}_{3}\right)$.

${ }^{4}$ Comparison of dietary DCAD effects (Basal, $\mathrm{NaCl}$, and $\mathrm{KCl}$ vs. $\mathrm{NaHCO}_{3}$ and $\mathrm{K}_{2} \mathrm{CO}_{3}$ ).

${ }^{5}$ Comparison of Basal vs. $\mathrm{NaCl}$ and $\mathrm{KCl}$.

${ }^{6}$ Thirty-five samples were used for the analysis of rumen ion concentrations. Thirty-four samples were used for the analysis of VFA concentrations.

${ }^{7}$ Twenty-eight samples were used for the analysis of rumen ion concentrations. Twenty-seven samples were used for the analysis of VFA concentrations.

${ }^{8}$ Rumen cation-anion difference: $\mathrm{Na}+\mathrm{K}-\mathrm{Cl}(\mathrm{mEq} / \mathrm{L})$. 
A)

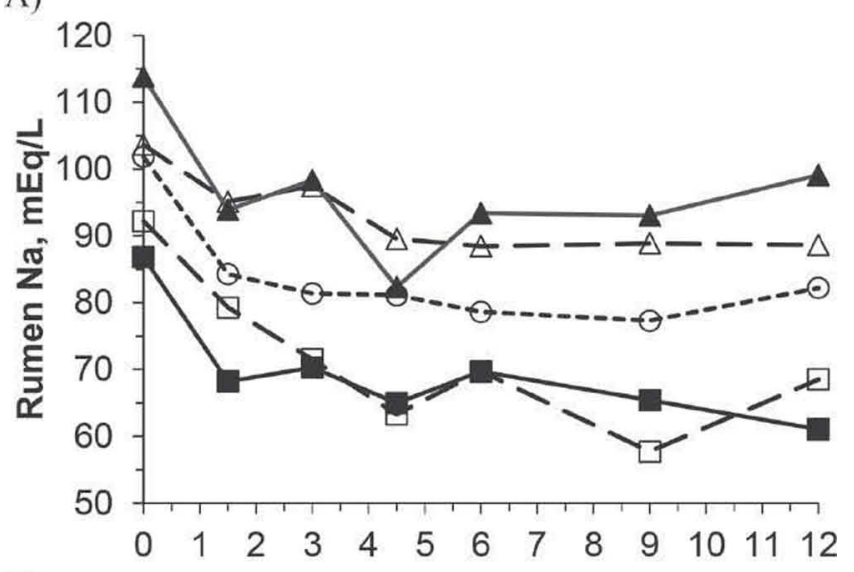

B)

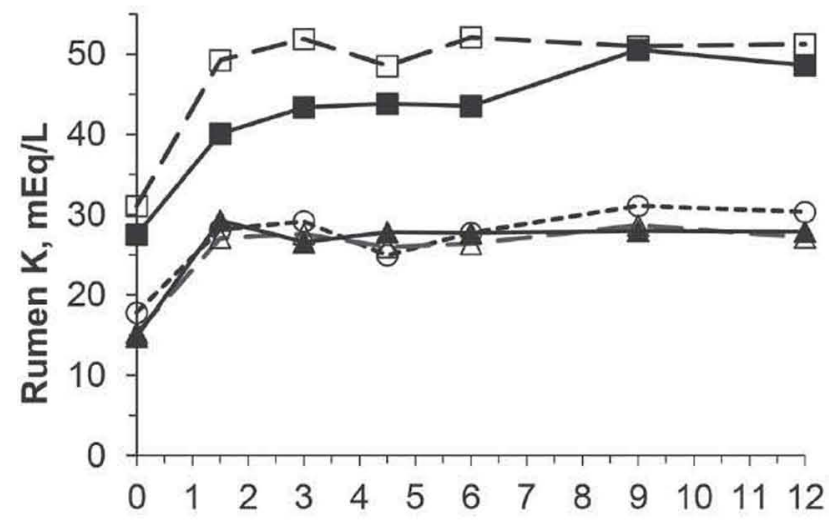

C)

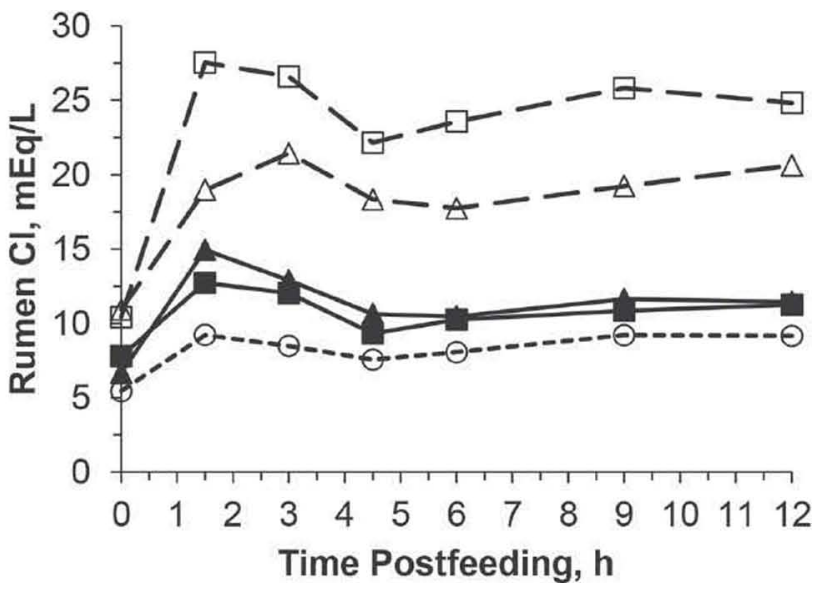

Figure 2. Time postfeeding effects on rumen strong ion concentrations. The basal diet (---O---) was supplemented with the indicated salt for the treatment diets. The $\mathrm{NaCl}$ diet $(--\Delta--)$ contained (DM basis) an additional $343 \mathrm{mEq} / \mathrm{kg}$ of $\mathrm{Na}$ and $\mathrm{Cl}$. The $\mathrm{KCl}$ diet (- - $\square--$ ) contained an additional $343 \mathrm{mEq} / \mathrm{kg}$ of $\mathrm{K}$ and $351 \mathrm{mEq} / \mathrm{kg}$ of $\mathrm{Cl}$. The $\mathrm{NaHCO}_{3}$ diet $(-\boldsymbol{\Delta}-)$ contained an additional $341 \mathrm{mEq} / \mathrm{kg}$ of $\mathrm{Na}$. The $\mathrm{K}_{2} \mathrm{CO}_{3}$ diet (- - ) contained an additional $343 \mathrm{mEq} / \mathrm{kg}$ of K. (A) Rumen Na: time postfeeding $(P=0.001)$; treatment by time postfeeding interaction $(P=0.091)$; SEM $=3.88$. (B) Rumen K: time postfeeding $(P=0.001)$; treatment by time postfeeding interaction $(P$ $=0.340)$; SEM $=2.60$. $(\mathrm{C})$ Rumen $\mathrm{Cl}$ : time postfeeding $(P=0.001)$ treatment by time postfeeding interaction $(P=0.260)$; $\mathrm{SEM}=2.36$.
In contrast to the decline in rumen $\mathrm{Na}$ with time postfeeding, rumen $\mathrm{K}$ increased with time postfeeding $(P$ $=0.001)$ and there was a trend for the effects of anion source $(P=0.091)$, where added dietary $\mathrm{Cl}$ reduced rumen $\mathrm{K}$ (Figure 2B). Rumen $\mathrm{Cl}$ concentrations increased $(P=0.001)$ nearly 2 -fold immediately after feeding and then remained nearly constant thereafter during the 12-h sampling period (Figure 2C). The absolute magnitude of the increase was greatest in the cows fed diets with added $\mathrm{Cl}$ (anion source; $P=0.001$ ), where cows fed added $\mathrm{Cl}$ had an $11 \mathrm{mEq} / \mathrm{L}$ increase in rumen Cl (Table 3).

The combination of reduced rumen $\mathrm{Na}$ and increased rumen $\mathrm{K}$ with time postfeeding resulted in a decline in rumen Na:K ratio with time postfeeding $(P=0.001$; Figure $3 \mathrm{~A}$ ). The Na:K ratio was on average 2.3 -fold higher in cows fed diets supplemented with $\mathrm{Na}$ compared with those supplemented with $\mathrm{K}(P=0.001)$. A plot of the raw data for rumen $\mathrm{K}$ versus $\mathrm{Na}$ (Figure $3 \mathrm{~B})$ showed an inverse relationship between rumen $\mathrm{Na}$ and $\mathrm{K}$, where a $1 \mathrm{mEq} / \mathrm{L}$ increase in rumen $\mathrm{Na}$ corresponded to a $0.53 \mathrm{mEq} / \mathrm{L}$ decrease in rumen $\mathrm{K}$.

Changes in RCAD followed changes in dietary DCAD, where increased DCAD increased $\operatorname{RCAD}(P=0.009$; Table 3 ). As expected, added dietary $\mathrm{Cl}$ reduced RCAD $(P=0.004)$; RCAD decreased with time postfeeding $(P$ $=0.001 ;$ data not presented).

Acetate was the only rumen VFA affected by dietary treatment (Table 3). Acetate averaged $4.2 \mathrm{mEq} / \mathrm{L}$ higher $(P=0.020)$ in cows fed the high DCAD diets $\left(\mathrm{NaHCO}_{3}\right.$ and $\left.\mathrm{K}_{2} \mathrm{CO}_{3}\right)$. Rumen acetate concentrations increased rapidly after feeding $(P=0.001)$ and remained elevated thereafter. There was no effect of treatment on the remaining rumen VFA. We detected time effects for propionate $(P=0.002)$, isobutyrate $(P=0.001)$, butyrate $(P=0.001)$, and valerate $(P$ $=0.001)$, where concentrations increased immediately after feeding. There was a trend for a DCAD effect in rumen acetate-to-propionate ratio $(P=0.058)$ but no time postfeeding effect. Total VFA concentrations (Figure 4$)$ were affected by time $(P=0.001)$ but not by treatment $(P=0.332$; Table 3$)$.

\section{DISCUSSION}

The results of this study support the hypothesis that dietary ion concentrations affect rumen ion concentrations. Rumen $\mathrm{Na}$ concentrations increased with increased dietary $\mathrm{Na}$ irrespective of the source of added $\mathrm{Na}\left(\mathrm{NaCl}\right.$ vs. $\left.\mathrm{NaHCO}_{3}\right)$. Previously, Bailey (1961) stated that salivary $\mathrm{Na}$ had a greater effect on rumen $\mathrm{Na}$ than dietary $\mathrm{Na}$, but that conclusion was based on the composition of $\mathrm{Na}$ in saliva versus feed and not actual flows of $\mathrm{Na}$ from saliva versus feed entry. Bailey and Balch 
(1961) found that types of feeds in the diet did not have a significant influence on salivary $\mathrm{Na}$ concentrations. We did not measure saliva $\mathrm{Na}$ in this experiment, but the present study clearly demonstrated that dietary $\mathrm{Na}$ has an effect on rumen $\mathrm{Na}$ concentration. Compared with the basal diet, $\mathrm{Na}$ addition increased rumen $\mathrm{Na}$ by $11 \mathrm{mEq} / \mathrm{L}$. We also showed that substituting dietary

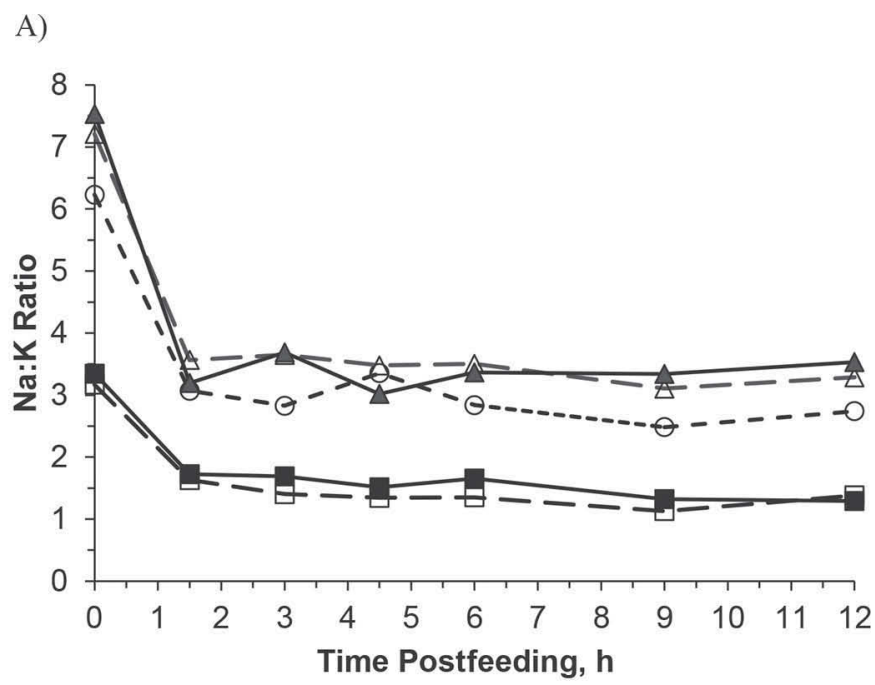

B)

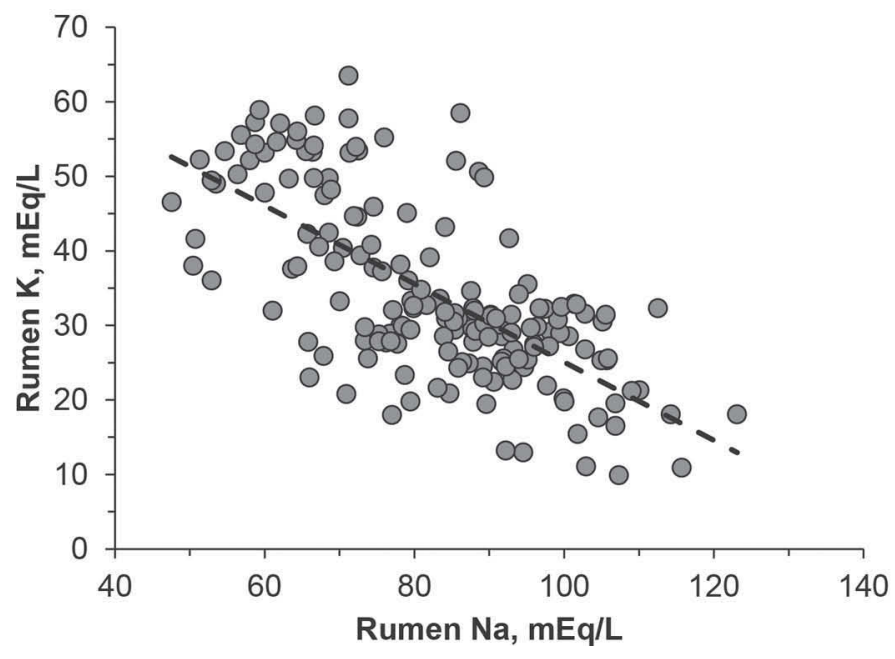

Figure 3. Time postfeeding effects on rumen Na:K ratio $(\mathrm{mEq} / \mathrm{L})$ and the relationship between rumen $\mathrm{Na}$ and $\mathrm{K}$. A) Time postfeeding effects $(P=0.001)$ and treatment by time postfeeding interaction $(P=0.011 ; \mathrm{SEM}=0.360)$. The basal diet $\left(---\mathrm{O}_{---}\right)$was supplemented with the indicated salt for the treatment diets. The $\mathrm{NaCl}$ diet $(--\Delta--)$ contained (DM basis) an additional $343 \mathrm{mEq} / \mathrm{kg}$ of $\mathrm{Na}$ and $\mathrm{Cl}$. The $\mathrm{KCl} \operatorname{diet}(--\square--)$ contained an additional $343 \mathrm{mEq} /$ $\mathrm{kg}$ of $\mathrm{K}$ and $351 \mathrm{mEq} / \mathrm{kg}$ of $\mathrm{Cl}$. The $\mathrm{NaHCO}_{3}$ diet (- - ) contained an additional $341 \mathrm{mEq} / \mathrm{kg}$ of $\mathrm{Na}$. The $\mathrm{K}_{2} \mathrm{CO}_{3}$ diet (- - contained an additional $343 \mathrm{mEq} / \mathrm{kg}$ of K. (B) Negative correlation between rumen $\mathrm{Na}$ and $\mathrm{K}$ concentrations across sampling times, where rumen $\mathrm{K}$ $(\mathrm{mEq} / \mathrm{L})=0.525 \times$ rumen Na $(\mathrm{mEq} / \mathrm{L})+77.6$; intercept $(P=0.001) ;$ intercept $\mathrm{SE}=3.63$; slope $(P=0.001)$; slope $\mathrm{SE}=0.043 ; \mathrm{R}^{2}=0.470$; root mean square error $=8.76$.

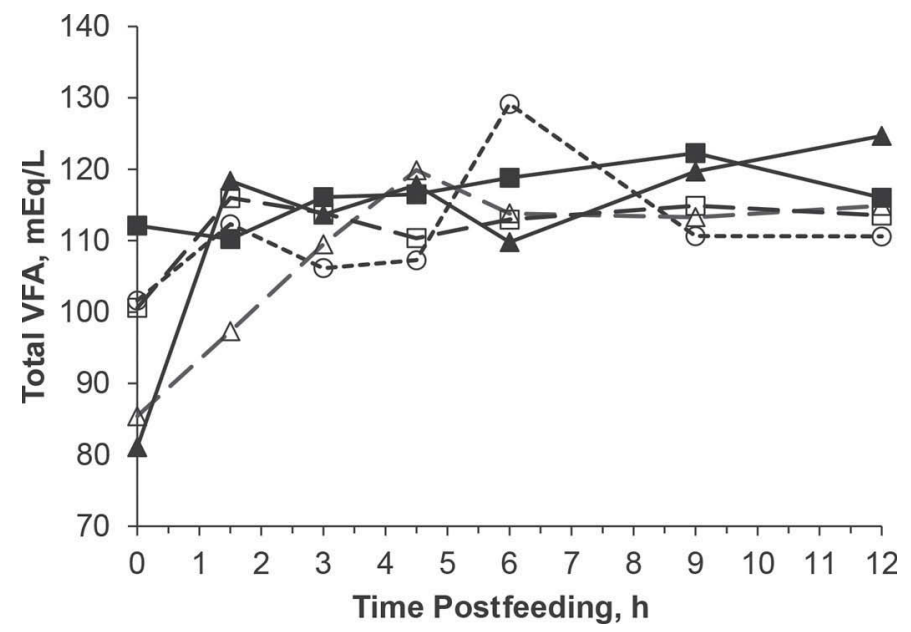

Figure 4. Time postfeeding $(P=0.001)$ and treatment by time postfeeding $(P=0.144)$ effects on rumen total VFA concentration $(\mathrm{mEq} / \mathrm{L})$. Time effects were significant $(P=0.001)$, but there were no time by treatment interactions $(P=0.144 ; \mathrm{SEM}=8.01)$. The basal diet (---○---) was supplemented with the indicated salt for the treatment diets. The $\mathrm{NaCl}$ diet $(--\Delta--)$ contained (DM basis) an additional $343 \mathrm{mEq} / \mathrm{kg}$ of $\mathrm{Na}$ and $\mathrm{Cl}$. The $\mathrm{KCl}$ diet $(--\square--)$ contained an additional $343 \mathrm{mEq} / \mathrm{kg}$ of $\mathrm{K}$ and $351 \mathrm{mEq} / \mathrm{kg}$ of Cl. The $\mathrm{NaHCO}_{3}$ diet (- - ) contained an additional $341 \mathrm{mEq} / \mathrm{kg}$ of Na. The $\mathrm{K}_{2} \mathrm{CO}_{3}$ $\operatorname{diet}(-\mathbf{-})$ contained an additional $343 \mathrm{mEq} / \mathrm{kg}$ of $\mathrm{K}$.

$\mathrm{K}$ for $\mathrm{Na}$ resulted in a $24 \mathrm{mEq} / \mathrm{L}$ or a $25 \%$ decrease in rumen $\mathrm{Na}$ concentration. The decrease in rumen $\mathrm{Na}$ concentrations postfeeding might be explained by increased Na absorption. Stacy and Warner (1966) found that $\mathrm{Na}$ absorption out of the rumen increased after feeding, and they concluded that the increased absorption was the response to increased osmotic pressure in the rumen. In addition, Warner and Stacy (1972) showed that increasing $\mathrm{Na}$ or $\mathrm{K}$ concentrations within the rumen increased the rate of sodium absorption.

Adding dietary $\mathrm{K}$ increased rumen $\mathrm{K}$ by $19 \mathrm{mEq} / \mathrm{L}$ demonstrating that diet $\mathrm{K}$ concentration alters rumen K. Several studies have shown that dietary K influences rumen K concentration (Bailey, 1961; Bennink et al., 1978). Bailey (1961) found that salivary K was always lower than rumen $\mathrm{K}$ concentration but there was a correlation between salivary $\mathrm{K}$ and rumen $\mathrm{K}$. In contrast to dietary $\mathrm{K}$ addition, which reduced rumen $\mathrm{Na}$ compared with the basal diet, addition of dietary $\mathrm{Na}$ had no effect on rumen K. Perhaps K absorption across the rumen wall is much slower and therefore $\mathrm{Na}$ absorption across the rumen wall is increased to maintain osmotic pressure and electrochemical neutrality.

In the present study, rumen $\mathrm{K}$ increased within the first $1.5 \mathrm{~h}$ after feeding with a greater time postfeeding effect in cows fed added K. Bennink et al. (1978) did not show clear time postfeeding effects on rumen $\mathrm{K}$ concentrations. However, in their experiments, dietary $\mathrm{K}$ was altered by selection of feed ingredients that var- 
ied in $\mathrm{K}$ content rather than by direct supplementation of $\mathrm{K}$, where $\mathrm{K}$ from supplements might be solubilized more rapidly than inherent $\mathrm{K}$ within feed ingredients. Tucker et al. (1988) found that DCAD did not affect rumen $\mathrm{Na}$ or $\mathrm{K}$ concentrations, but they did note an inverse relationship between the 2 ions in the rumen. Other studies have also discussed the inverse relationship between rumen $\mathrm{Na}$ and $\mathrm{K}$ concentrations (Poutiainen, 1968; Warner and Stacy, 1972). Although the basal, $\mathrm{KCl}$, and $\mathrm{K}_{2} \mathrm{CO}_{3}$ diets contained similar amounts of $\mathrm{Na}$, the basal diet had $13.2 \mathrm{mEq} / \mathrm{L}$ higher rumen $\mathrm{Na}$ concentrations than the $\mathrm{K}$ diets.

In our study, rumen $\mathrm{Cl}$ increased with increased dietary Cl. Bennink et al. (1978) found that dietary $\mathrm{Cl}$ did not directly influence rumen $\mathrm{Cl}$ concentrations, but again, this was by selecting feeds with high $\mathrm{Cl}$ rather than using direct supplementation of $\mathrm{NaCl}$ and $\mathrm{KCl}$ that we used. The alfalfa pellet diet used in the Bennink et al. (1978) study had the highest dietary $\mathrm{Cl}$ concentration but resulted in the lowest rumen $\mathrm{Cl}$ concentration. Bennink et al. (1978) suggested that this could have been due to differences in the elution rate of ions from the different types of feeds. Alternatively, alfalfa also has high $\mathrm{K}$ content so there could have been confounding effects of dietary $\mathrm{Cl}$ and $\mathrm{K}$. In contrast, Bailey (1961) reported that dietary $\mathrm{Cl}$ concentrations did affect rumen $\mathrm{Cl}$ concentrations, with dietary concentrations having more influence than saliva on rumen $\mathrm{Cl}$. Cows had similar rumen $\mathrm{Cl}$ concentrations when they were fed the same diets, and diets with higher $\mathrm{Cl}$ concentrations tended to have higher rumen $\mathrm{Cl}$ concentrations (Bailey, 1961).

Although the data from this study suggest a significant DCAD effect on rumen $\mathrm{Cl}$ concentrations, it is likely that the effect was the result of the increased $\mathrm{Cl}$ in the lower DCAD diets $(\mathrm{NaCl}$ and $\mathrm{KCl})$ and not the actual DCAD itself. The basal diet produced rumen $\mathrm{Cl}$ concentrations similar to that of the higher DCAD diets. Tucker et al. (1988) found that increased DCAD tended to decrease rumen $\mathrm{Cl}$ concentrations; however, the present study contradicts those results. The discrepancy between the 2 studies could be the result of the different ways DCAD was manipulated. Tucker et al. (1988) altered the DCAD using different combinations of $\mathrm{Na}, \mathrm{K}$, and $\mathrm{Cl}$ for each specific DCAD that they studied. Unfortunately, they pooled results for the rumen ion concentrations by DCAD instead of reporting them for the 3 different dietary combinations that they used to achieve each DCAD, so direct dietary comparison with their rumen $\mathrm{Cl}$ concentrations is not possible (Tucker et al., 1988).

The increase in rumen $\mathrm{pH}$ with increased DCAD was consistent with the predicted response from a metaanalysis of DCAD effects (Iwaniuk and Erdman, 2015).
In that analysis, an increase in DCAD of $1 \mathrm{mEq} / \mathrm{kg}$ of diet DM was predicted to result in a 0.0003-unit increase in rumen $\mathrm{pH}$. In the current study, addition of $\mathrm{K}_{2} \mathrm{CO}_{3}$ and $\mathrm{NaHCO}_{3}$ increased DCAD by $345 \mathrm{mEq} /$ $\mathrm{kg}$ and would have been predicted to increase rumen $\mathrm{pH}$ by 0.1035 units, which is nearly identical to the measured change of $0.108 \mathrm{pH}$ units.

In this study, cation source did not affect rumen $\mathrm{pH}$. A literature review by Erdman (1988) discussed the benefits of using buffers such as $\mathrm{NaHCO}_{3}$ and $\mathrm{K}_{2} \mathrm{CO}_{3}$ to reduce the decrease in rumen $\mathrm{pH}$ associated with time postfeeding. When Vagnoni and Oetzel (1998) used anionic salts to decrease DCAD, they found that rumen pH also decreased. Similarly, Tucker et al. (1988) reported that rumen $\mathrm{pH}$ was lower when using a negative DCAD than when using a neutral or positive DCAD.

In this study, rumen VFA concentration was not affected by cation source or DCAD. Similarly, ApperBossard et al. (2010) reported no significant changes in VFA concentration with altered DCAD. Although rumen acetate was $4.2 \mathrm{mEq} / \mathrm{L}$ higher with the higher DCAD diets, there were no differences for the other VFA or total VFA concentration. Tucker et al. (1988) only noted a tendency for decreased total VFA concentrations and increased isovalerate concentrations with increased DCAD.

Changes in dietary $\mathrm{Na}$ and $\mathrm{K}$ were clearly shown to affect their respective rumen ion concentrations, especially when dietary $\mathrm{K}$ was increased, which resulted in a $19.0 \mathrm{mEq} / \mathrm{L}$ increase in rumen $\mathrm{K}$ and a $24 \mathrm{mEq} / \mathrm{L}$ decrease in rumen Na. Increasing dietary K by $340 \mathrm{mEq} /$ $\mathrm{kg}$ of DM reduced the rumen Na:K ratio from 3.96:1 to 1.71:1 such that Na was reduced from 80 to $63 \%$ of the total strong ion concentration in the rumen. Hypothetically, such a shift in rumen $\mathrm{Na}$ and $\mathrm{K}$ concentrations might be sufficient to mediate the effects of ionophores on rumen fermentation. Monensin preferentially binds $\mathrm{Na}$ ions over K ions (McGuffey et al., 2001). Although lasalocid preferentially binds $\mathrm{K}$ ions, it can also bind $\mathrm{Na}$ ions (McGuffey et al., 2001).

Using pure cultures of Eubacterium ruminantium 2388, Streptococcus bovis C277, Lactobacillus casei LB17, and Prevotella albensis M384, Newbold et al. (2013) demonstrated increased monensin sensitivity in rumen bacteria by increasing media Na from 132 to 177 $\mathrm{mEq} / \mathrm{L}$. Conversely, increasing media K concentrations from 19 to $35 \mathrm{mEq} / \mathrm{L}$ decreased monensin sensitivity in these same species. Although even the lowest Na concentrations used by Newbold et al. (2013) were greater than the rumen Na concentrations observed in the present study, the $\mathrm{K}$ concentrations were not dissimilar from the range (26 to $48 \mathrm{mEq} / \mathrm{L}$ ) measured herein. However, measurement of differences in monensin sensitivity in pure culture to varying $\mathrm{Na}$ and $\mathrm{K}$ media concentrations 
is quite different from determination of their potential in vivo responses. Feeding experiments with varying dietary $\mathrm{Na}$ and $\mathrm{K}$ would be required to determine if there are potential mediating effects of strong ion sources on animal performance in responses to monensin feeding. This experiment demonstrated only that $\mathrm{Na}, \mathrm{K}$, and $\mathrm{Cl}$, the major strong ions in the rumen, could be modulated by varying the dietary concentrations of those ions.

Finally, it is likely that added mineral supplements increased water intake, but we did not measure water intake. Regression equations developed by Murphy et al. (1983) suggested a $0.05 \mathrm{~kg} / \mathrm{d}$ increase in water intake per gram increase in sodium intake. Spek et al. (2012) reported a $44 \mathrm{~kg} / \mathrm{d}$ increase in water intake as $\mathrm{Na}$ intake increased from 67 to $417 \mathrm{~g} / \mathrm{d}$. The mean $\mathrm{Na}$ intakes were $59,247,58,247$, and $56 \mathrm{~g} / \mathrm{d}$ and $\mathrm{K}$ intakes were $366367,687,362$, and $672 \mathrm{~g} / \mathrm{d}$ in the Basal, $\mathrm{NaCl}, \mathrm{KCl}, \mathrm{NaHCO}_{3}$, and $\mathrm{K}_{2} \mathrm{CO}_{3}$ treatments, respectively. Predicted urine output based on $\mathrm{Na}$ and $\mathrm{K}$ intake (Bannink et al., 1999) would be 28, 51, 47, 50, and $46 \mathrm{~kg} / \mathrm{d}$ for the respective treatments. However, it is uncertain how changes in water intake would affect rumen ion concentrations because concentrations would depend on a variety of factors, including rumen water balance, rumen ion absorption and influx across the rumen wall, rates of liquid passage from the rumen, and salivary flow in addition to feed ion concentrations.

\section{CONCLUSIONS}

This study demonstrated that manipulation of dietary strong ion concentrations can alter rumen ion concentrations. Increasing dietary concentrations of $\mathrm{Na}, \mathrm{K}$, and $\mathrm{Cl}$ increased their respective rumen ion concentrations, and we detected an inverse relationship between rumen $\mathrm{Na}$ and $\mathrm{K}$ concentrations. Increasing DCAD by substitution of bicarbonate and carbonate salts for $\mathrm{Cl}$ salts of $\mathrm{Na}$ and $\mathrm{K}$ had a respective effect on RCAD and the balance between $\mathrm{Na}, \mathrm{K}$, and $\mathrm{Cl}$ ion concentrations in the rumen. Therefore, if production and feed efficiency responses to DCAD and potentially ionophores in the diet are affected by rumen $\mathrm{Na}$ and $\mathrm{K}$ concentrations, then manipulating dietary $\mathrm{Na}$ and $\mathrm{K}$ could be used to either enhance or diminish those responses.

\section{ACKNOWLEDGMENTS}

The authors thank Melissa Shaughness and Tim Shellem from the University of Maryland for their assistance with diet preparation, feeding, animal husbandry, and sample collection. The authors also thank Brian Spielman, Michael Dwyer, and the remaining staff at the Central Maryland Research and Education Center (CMREC, Clarksville) for their assistance in feeding and caring for the cows used for this study. The authors thank Arm \& Hammer Animal Nutrition (Piscataway, NJ) for partial support of this study.

\section{REFERENCES}

Agilent Technologies. 2015. Flame Atomic Absorption Spectrometry. 12th ed. Agilent Technologies Australia (M) Pty, Ltd., Mulgrave, Victoria, Australia.

Apper-Bossard, E., P. Faverdin, F. Meschy, and J. L. Peyraud. 2010. Effects of dietary cation-anion difference on ruminal metabolism and blood acid-base regulation in dairy cows receiving 2 contrasting levels of concentrate in diets. J. Dairy Sci. 93:4196-4210.

Bailey, C. B. 1961. Saliva secretion and its relation to feeding in cattle. 4. The relationship between the concentrations of sodium, potassium, chloride and inorganic phosphate in mixed saliva and rumen fluid. Br. J. Nutr. 15:489-498.

Bailey, C. B., and C. C. Balch. 1961. Saliva secretion and its relation to feeding in cattle. 2. The composition and rate of secretion of mixed saliva in the cow during rest. Br. J. Nutr. 15:383-402.

Bannink, A., H. Valk, and A. M. Van Vuuren. 1999. Intake and excretion of sodium, potassium, and nitrogen and the effects on urine production by lactating dairy cows. J. Dairy Sci. 82:1008-1018.

Bennink, M. R., T. R. Tyler, G. M. Ward, and D. E. Johnson. 1978 Ionic milieu of bovine and ovine rumen as affected by diet. J. Dairy Sci. $61: 315-323$.

Cumberland Valley Analytical Services. 2016. Lab Procedures. Accessed April 1, 2016. http://www.foragelab.com/Resources/ Lab-Procedures.

Ender, F., I. W. Dishington, and A. Helgebostad. 1962. Parturient paresis and related forms of hypocalcaemic disorders induced experimentally in dairy cows. Acta Vet. Scand. 3(Suppl. 1):5-52.

Erdman, R. A. 1988. Dietary buffering requirements of the lactating dairy cow: A review. J. Dairy Sci. 71:3246-3266.

Erdman, R. A. 2011. Benchmark dairy feed efficiency. Feedstuffs $82: 16-19$.

Funk, M. A., M. L. Galyean, and T. T. Ross. 1986. Potassium and lasalocid effects on performance and digestion in lambs. J. Anim. Sci. 63:685-691.

Hu, W., and L. Kung Jr.. 2009. Effect of dietary ratio of Na:K on feed intake, milk production, and mineral metabolism in mid-lactation dairy cows. J. Dairy Sci. 92:2711-2718.

Hu, W., and M. R. Murphy. 2004. Dietary cation-anion difference effects on performance and acid-base status of lactating dairy cows: A meta-analysis. J. Dairy Sci. 87:2222-2229.

Ipharraguerre, I. R., and J. H. Clark. 2003. Usefulness of ionophores for lactating dairy cows: A review. Anim. Feed Sci. Technol. 106:39-57.

Iwaniuk, M. E., and R. A. Erdman. 2015. Intake, milk production, ruminal, and feed efficiency responses to dietary cation-anion difference by lactating dairy cows. J. Dairy Sci. 98:8973-8985.

Iwaniuk, M. E., A. E. Weidman, and R. A. Erdman. 2015. The effect of dietary cation-anion difference concentration and cation source on milk production and feed efficiency in lactating dairy cows. J. Dairy Sci. 98:1950-1960

McGuffey, R. K., L. F. Richardson, and J. I. D. Wilkinson. 2001. Ionophores for dairy cattle: Current status and future outlook. J. Dairy Sci. 84(E. Suppl.):E194-E203.

Mongin, P. 1981. Recent advances in dietary anion-cation balance: Applications in poultry. Proc. Nutr. Soc. 40:285-294.

Murphy, M. R., C. L. Davis, and G. C. McCoy. 1983. Factors affecting water consumption by Holstein cows in early lactation. J. Dairy Sci. $66: 35-38$

NRC. 2001. Nutrient Requirements of Dairy Cattle. 7th rev. ed. Natl. Acad. Press, Washington, DC.

Newbold, C. J., R. J. Wallace, and N. D. Walker-Bax. 2013. Potentiation by metal ions of the efficacy of the ionophores, monensin 
and tetronasin, towards four species of ruminal bacteria. FEMS Microbiol. Lett. 338:161-167.

PerkinElmer. 1996. Analytical Methods for Atomic Absorption Spectroscopy. PerkinElmer Inc., Norwalk, CT.

Poutiainen, E. 1968. Factors influencing the flow of fluid, saliva and some cations through the reticulo-omasal orifice of the cow. Annales Agriculturae Fenniae 7:1-6.

Rumpler, W. V., D. E. Johnson, and D. B. Bates. 1986. The effect of high dietary cation concentration on methanogenesis by steers fed diets with and without ionophores. J. Anim. Sci. 62:1737-1741.

Sanchez, W. K., D. K. Beede, and J. A. Cornell. 1994. Interactions of sodium, potassium, and chloride on lactation, acid-base status, and mineral concentrations. J. Dairy Sci. 77:1661-1675.

Spek, J. W., A. Bannink, G. Gort, W. H. Hendriks, and J. Dijkstra. 2012. Effect of sodium chloride intake on urine volume, urinary urea excretion, and milk urea concentration in lactating dairy cattle. J. Dairy Sci. 95:7288-7298.
Stacy, B. D., and A. C. I. Warner. 1966. Balances of water and sodium in the rumen during feeding: Osmotic stimulation of sodium absorption in the sheep. Q. J. Exp. Physiol. Cogn. Med. Sci. 51:79-93.

Tucker, W. B., G. A. Harrison, and R. W. Hemken. 1988. Influence of dietary cation-anion balance on milk, blood, urine, and rumen fluid in lactating dairy cattle. J. Dairy Sci. 71:346-354.

Vagnoni, D. B., and G. R. Oetzel. 1998. Effects of dietary cationanion difference on the acid-base status of dry cows. J. Dairy Sci 81:1643-1652.

Warner, A. C. I., and B. D. Stacy. 1972. Intraruminal and systemic responses to variations in intake of sodium and potassium by sheep. Q. J. Exp. Physiol. 57:89-102.

Wildman, C. D., J. W. West, and J. K. Bernard. 2007. Effects of dietary cation-anion difference and potassium to sodium ratio on lactating dairy cows in hot weather. J. Dairy Sci. 90:970-977. 